DOI: https://doi.org/10.34069/AI/2021.44.08.5

How to Cite:

Asieieva, Y., Aymedov, C., Horishchak, S., Mierlich, S., \& Riabukhin, K. (2021). Cyber-addictions of the Ukrainian youth. Amazonia Investiga, 10(44), 48-60. https://doi.org/10.34069/AI/2021.44.08.5

\title{
Cyber-addictions of the Ukrainian youth
}

\section{Кіберадикції української молоді}

Received: July 10, 2021

\section{Abstract}

The work is devoted to the study of the problem of dependence on cyberspace of young people. Experts increasingly believe that cyber-addiction is a pathological urge or disease that belongs to the category of non-chemical dependencies and has its own nosology, etiology, pathogenesis and requires prevention, treatment and psychocorrection. Thanks to the analysis of scientific achievements, their actual types were determined, a comprehensive model of classification was built taking into account socially accepted, pathological and cyberaddiction; the stages of cyber-addiction formation are separated.

Thanks to the developed and tested method «Test-questionnaire for detecting cyberaddiction», it was found that the most typical addictions for young people are: computer addiction, Internet addiction, game addiction and gadget addiction; girls are more typical: cyber communicative addiction and selfitis. When considering age characteristics, it was found that the highest rates of 3rd degree of addiction are among people aged 19 to 21 , a more even distribution of 2 nd and 3 rd degrees of addiction
Accepted: August 25, 2021

Written by:

Asieieva Yuliia ${ }^{19}$

https://orcid.org/0000-0003-3086-3993

Aymedov Constantine ${ }^{20}$

https://orcid.org/0000-0003-2577-0151

Horishchak Serhii ${ }^{21}$

https://orcid.org/0000-0002-5585-6370

Mierlich Sergii ${ }^{22}$

https://orcid.org/0000-0003-1360-3882

Riabukhin Konstiantyn ${ }^{23}$

https://orcid.org/0000-0003-2204-7283

\section{Анотація}

Робота присвячена дослідженню проблеми залежності від кіберпростору молоді. Погляди фахівців все більше зводяться до того, що кіберадикція - це патологічний потяг чи захворювання, яке належить до категорії нехімічних залежностей і має свою власну нозологію, етіологію, патогенез і потребує профілактики, лікування та психокорекції. Завдяки проведеному аналізу наукових надбань, були визначені їх актуальні види, побудовано всебічну модель класифікації 3 урахуванням соціально прийнятих, патологічних та кіберадикцій; відокремлено стадії формування кіберадикцій.

Завдяки розробленій та апробованій методики «Тест-опитувальник на виявлення кіберадикції» було, встановлено, що найбільш характерними адикціями для юнаків є: комп'ютерна залежність, Інтернетадикція, ігрова адикція та гаджет-адикція; дівчатам більш притаманні: кіберкомунікативна адикція та селфітіс. При розгляді вікових особливостей було виявлено, що найвищі показники за 3-м ступенем прояву адикцій знаходяться серед

\footnotetext{
${ }^{19} \mathrm{PhD}$, Head of the Department of General Scientific, Social and Behavioral Disciplines of the Odessa Institute of the Interregional Academy of Personnel Management, Ukraine.

${ }^{20} \mathrm{MD}$, Doctor of Medical Sciences, Professor, Odessa National Medical University, Ukraine.

${ }^{21} \mathrm{PhD}$, Candidate of Medical Sciences, Director, Municipal Non-Commercial Enterprise "Children's City Polyclinic № 6" of Odessa City Council: Odessa, Ukraine.

${ }^{22} \mathrm{PhD}$, Candidate of Medical Sciences, Surgeon-Oncologist of the highest category, Department of General Surgery, Odessa National Medical University Ukraine.

${ }^{23} \mathrm{PhD}$, Candidate of Medical Sciences, Psychiatrist, narcologist, medical psychologist, doctor of the highest category, Assistant of the Department of Psychiatry and Narcology, Odessa National Medical University, Ukraine.
} 


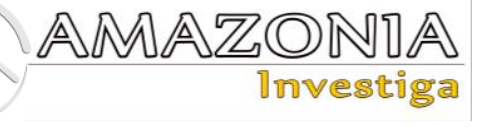

among people aged 14 to 15 years. Due to the factor analysis of the obtained results, it was established that an addict can have not one dependence, but several, although each of them may have a different degree of manifestation.

Key words: cyberspace, interactive technologies, non-chemical dependence, cyberaddiction, Internet, social networks.

осіб від 19 до 21 року, більш рівномірний розподіл 2-го та 3-го ступенів адикцій серед осіб у віковій категорії від 14 до 15 років. Завдяки проведеному факторному аналізу отриманих результатів встановлено, що адикт може мати не одну залежність, а декілька, хоча кожна із них може мати різний ступінь прояву.

Ключові слова: кіберпростір, інтерактивні технології, нехімічна залежність, кіберадикції, Інтернет, соціальні мережи.

\section{Introduction}

Formulation of the problem. The prevalence of interactive technologies and widespread computerization is due to socio-anthropogenic factors, easy availability and ease of use of electronic devices that allow easy information retrieval, expand the possibilities of interconnection and interpersonal communication, which in today's urbanization saves time and performing professional or educational activities, allows you to receive, store and process huge amounts of information. Computer and interactive technologies are penetrating education, science, economics, politics, culture, and more. The Internet reflects the functioning of various sectors of society and provides information services for communication, leisure and other activities, including professional. The Internet is necessary for everyone - regardless of profession, social status, age and gender differences. The Internet as a means of personal development significantly contributes to its self-realization and expands social opportunities. Network users not only consume information, but also constantly fill it with various information resources (Markova, 2013; Utz, 2015).

Increasingly, we are finding research on the prevalence of Internet addiction, cyberadication and gadget addiction among children, adolescents and young people. However, it should be noted that systematic studies of the prevalence of Internet addiction and its impact on the personality of the adolescent has not been conducted (Bolbot, 2005; Pronin, 2016; Rybaltovich et al, 2012; Blachnio, Przepiorka, Benvenuti, Mazzoni, \& Gwendolyn, 2019; Hawi, 2018).

Escape from real interpersonal communication into cyberspace leads to loss of communication skills, empathy, the development of alexithymia and the emergence of asociality, the development of maladaptation and reduced stress. In the early

stages of immersion in cyberspace, all this goes unnoticed, conversations are replaced by messengers, real meetings with video chats or video calls, significant social groups are inferior to teams when playing online networks. Gradually, the individual loses connection and adaptability in real social life, there is anxiety when it is necessary to meet in real life, public speeches or a large number of people cause feelings of danger, fear. Active social life is imperceptibly replaced by cyberspace and cybercommunication, and social approval, respect, and esteem are replaced by "likes" (Goncharov, 2011; Grybyuk, Demyanenko, 2014; Tazetdinova, 2018; Oravec, 2012; Tan, 2016).

All these and other debatable issues regarding the development and formation of the gaming industry and its impact on the fictitious personality confirm the relevance of research on the psychological characteristics of the involvement of adolescents and young people in the virtual environment.

The purpose: to investigate the dominant cyberaddiction of Ukrainian youth. Since different types of c cyber-addiction may prevail among young people, they can be classified by direction and content, to explore their combination.

The study of the specifics and severity of types of cyber-addiction among young people will give us the opportunity not only to describe the psychological characteristics, but also to approach the development of adequate psychological technologies for their prevention, prevention and psychocorrection.

\section{Objectives}

1. To clarify the meaning of the concept of cyber-addiction. 
2. To provide a classification of species and to reveal the specifics of the manifestations of cyber-addiction, taking into account their stages. 3. To investigate and describe the dominant cyber-addiction among young people according to the degree of their manifestation.

\section{Research methods}

The following methods were used during the research: theoretical and interdisciplinary analysis, complex, psychodiagnostic and methods of mathematical and statistical data processing.

The theoretical method included theoretical and methodological analysis, generalization of various scientific materials on the topic of the study, as well as a systematization of available modern literature on the prevalence and classification of cyber-addiction among Ukrainian youth.

Interdisciplinary analysis of social, psychological, medical, pedagogical literature is aimed at reflecting the current state of the problem of cyber-addiction and creating your own conceptual model.

The comprehensive method included: a survey and a structured interview, which provided the opportunity to obtain the necessary data, namely age, gender, level of education, family status (complete, incomplete, the presence of guardians, etc.). Interviews with respondents and their parents clarified some data on the life and intensity of adolescent passion, complemented the picture of the anamnesis.

Psychodiagnostic research method. It is chosen to determine the main macro- and microsocial individual-biological, individual-psychological and personal-psychological factors of cyberaddiction formation as markers of further psycho-correctional work. The experimental study was aimed at determining the predisposition to addictive behavior and the degree of manifestation of some types of cyberaddiction, conducted using: Test-questionnaire to detect cyber-addiction (TQC), which proved its validity, standardization and reliability (published in the author's work). The TQC includes 102 questions, the answers are evaluated on a five-point scale, which allows to determine the degree of manifestation of certain types of cyber-addiction: computer addiction (PC), Internet addiction, game addiction, gadget addiction, cyber-communication addiction and selfitis.
Statistical data processing was performed using SPSS 26.0 for Windows XP, which allowed to build profiles and provide quantitative and qualitative analysis of the obtained data.

\section{Analysis of recent research and publications}

The social formation of the individual takes place in two planes - material and cyber-reality, each of which allows the individual to be realized in its various manifestations, but cyberspace is more attractive because it allows you to try on many more images of self, as well as refuse to communicate and connections with unwanted persons, etc. Therefore, already now the scale of cyber-addiction, Internet addiction, gadget addiction and other non-chemical addictions associated with interactive technologies are so significant that they are allocated to a number of new ones that significantly affect the formation of youth and society as a whole (Aymedov, Asieieva, Tolmachev, \& Tabachnik, 2020; Borisova, \& Soltan, 2019; Boram, \& Yoon, 2020; Stefanie, Streb, \& Irina, 2019; Yaxuan, \& Lin, 2018; Blachnio, Przepiorka, Benvenuti, Mazzoni, \& Gwendolyn, 2019).

The first studies on the impact of humanitarian information technology were published in the field of social psychology in the 70's: Short J., Williams E., \& Christie B. (1976), Hiltz S.R., \& Turoff M. (1978) (Short, Williams \& Christie, 1976; Hiltz, Turoff, 1978). The scientists' work was devoted to communication via a local or global network, while at that time there was only an interdependent computer network. In the next decade, researchers are attracted to research aimed at studying the communicative aspect and analyzing the impact of the network on organizational structures. Thus, in the works of M. Shotton (1991) Marlatt G.A., Baer J.S., Donovan D.M., \& Kivlahan D.R. (1988) the concept of computer dependence appears, the first types are separated and the psychological characteristics of addicts are described. In the 90 's, the vector of scientists' attention is directed to the Internet itself, and in addition to interpersonal communication, gaming and cognitive activities began to be explored using the World Wide Web. In this decade, the first diagnostic tools for the detection of Internet addiction (Young, K., 1996) (Young, 1996) and described the individual psychological characteristics of people with computer addiction (Goldberg, 1996). This disorder is also considered in the medical field, the symptoms are studied and there is an active search for treatment and rehabilitation programs. 


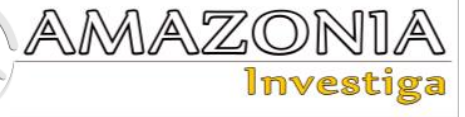

Since the early 2000s, the views of the psychological, social and medical scientific community (Voiskunsky, Ye., Smyslova, O.V., Bolbot, T., Melnik, E., Belinskaya, E.P., Voloshin, P.V, Maruta, N.O., Griffiths, M.D. etc.) are directed to a more detailed study of computer and the Internet dependencies, are already beginning to separate: various definitions, socio-psychological factors of formation, symptoms and stages, clinical aspects, classifications and typologies, highlighted issues of children's interaction with the computer, the behavior of users in the network and more.

At present, the problem of dependence on cyberspace is seen as multidisciplinary in three main areas: psychological, social and medical. From the standpoint of social direction, the fascination with cyberspace is seen as a kind of deviation. The views of physicians and psychologists have recently been reduced to the position that cyber-addiction is a pathological urge or disease that belongs to the category of non-chemical dependencies and has its own nosology, etiology, pathogenesis and needs prevention, treatment and psychocorrection.

It should also be noted that despite the multidisciplinary problem of cyber-addiction, there is still no clear classification of this type of non-chemical dependence, most psychodiagnostic tools for their detection are adapted, not created taking into account the mentality and sociocultural characteristics of addicts. Symptoms and anamnesis are insufficiently described, the criteria for distinguishing between Internet addictions, computer addictions, gambling addiction are not clearly defined, and some new types of cyberaddiction are hardly studied and not taken into account at all.

\section{Results}

Clarification of the concept of "cyberaddiction".

Computer addiction, Internet addiction and cyber-addiction are interpreted by most scientists as a mental disorder that affects the normal process of a person's life and has its own variants of manifestation and process of flow Yu. D. Babaeva, O.E. Voiskunsky. According to researchers, the most relevant for adolescence are the following types of dependence on cyberspace (Zhaojun, Pontesbc, \& Guangcan, 2020). First, it is a passion for virtual dating, even the redundancy of acquaintances and friends on the social network, because it is adolescence is

characterized by the establishment of interpersonal relationships with peers. Second, the obsession with the network, namely gambling, is most prevalent in online gambling, regular shopping, or bidding. Third, obsessive web surfing, that is, the urge for information overload - endless travel on the network, searching for information in databases and search sites. And fourth, it is a computer addiction - an obsessive game in computer games: shooters (Doom, Quake, Unreal, etc.), strategy games such as Star Craft, quests, computer role-playing games: Planescape: Torment; The Elder Scrolls, Wizardry series, Ultima, Fallout, Gothic series, Baldur's Gate, Might \& Magic, etc. (Rzhevsky, 2018; Bartkiv, \& Makhnovets, 2018; Aymedov, Asieieva, Tolmachev, \& Tabachnik, 2020; Chebykin, 2016; Blachnio, Przepiorka, Benvenuti, Mazzoni, \& Gwendolyn, 2019; Hiltz, \& Turoff, 1978; Babaeva, Voiskunsky, \& Smyslova, 2005; Zhaojun, Pontesbc, \& Guangcan, 2020; Griffiths, Kuss, \& Billieux, 2016).

In our opinion, it is possible to separate three directions of negative influence of daily use of the computer (PC). First, the computer has become a means of administrative and coercive nature, today it is impossible to obtain secondary and higher education, as well as employment without a minimum knowledge of PC and its minimum Windows package. Secondly, the forced imposition of constant self-development within computer technology, that is, a person aims to identify himself through the prism of computer literacy and the ability to learn new applied information to modify their own PC, constant monitoring of innovation in the information technology market. Third, the computer and the Internet are in constant communication and become a means of psychologically replacing material reality with cyberspace.

Replacing real interpersonal communication with cybercommunication leads to loss of communication skills, empathy, development of alexithymia and the appearance of asociality, development of maladaptation and reduction of stress resistance. In the first stages of immersion in cyberspace, all this goes unnoticed, conversations are replaced by messages in messengers, real meetings - video chats or video calls, significant social groups are inferior to teams when playing online in networks. Gradually, the individual loses connection and adaptability in real social life, there is anxiety when it is necessary to meet in real life, public speeches or a large number of people begin to 
cause feelings of danger, fear. Active social life is imperceptibly replaced by cyberspace and cybercommunication, and social approval, respect, reverence are replaced by «likes» (Utz, 2015; Aymedov, Asieieva, Tolmachev, \& Tabachnik, 2020; Chebykin, 2016; Boram, \& Yoon, 2020; Yaxuan, \& Lin, 2018; Babaeva, Voiskunsky, \& Smyslova, 2014).

In the modern scientific literature, we increasingly encounter the assertion that addictive behavior occurs as a result of complex interactions of hereditary, biochemical, social and individual psychological factors. Among these are: external conditions of the physical environment; internal hereditary-biological, psychophysiological and individual-typological prerequisites; external social conditions; intrapersonal causes and mechanisms of dependent behavior.

Summarizing the manifestations characteristic of Internet addiction and computer addiction, we can distinguish the main features of cyberaddiction: the impossibility of subjective control over the use of cyberspace and maladaptation, which reflects the negative impact of its use on interpersonal relationships, health, work, learning, emotional, psychological state, financial status, etc., are characteristic, however, for any dependent behavior. Cyber-addiction, as a painful disorder, corresponds to the known six components that are universal for all variants of addictions: feature, «superiority»; mood swings; increasing tolerance; withdrawal symptoms; conflict with others and yourself; relapse.

Based on the considered scientific and theoretical achievements, in our opinion, all the separate determinants can be divided into three criteria predisposing, contributing and supporting. Biological predisposing determinants include: adolescence (14-21 years); encumbrance of heredity; organic brain damage; degree of initial tolerance; temperament features; genetic predisposition to addictions. Among the psychological predisposing determinants can be distinguished: disharmonious functioning of the emotional sphere; impaired ability to reflect; impaired self-esteem; psychological isolation; psychological immaturity; the presence of at least one frustrated need. To the social predisposing determinants - the formation of a destructive social image of «I»; breaking family ties; social disorientation in microsocial conditions.

Contributing biological factors to the formation of cyber-addiction can be considered: chronic diseases; predisposition to depression; suicidal tendencies; neuroticism. The group of contributing psychological determinants include: violations in the acceptance of their physical "I"; feelings of loneliness; tendency to negativism; tendency to avoid problems and responsibilities; type of accentuation; interest; the presence of psychological trauma in different periods of life. Among the social contributing determinants are: disorders in intimate-personal relationships; authority of the reference antisocial group.

Supporting biological determinants are individual differences in the work of neurotransmitter and neuromodulatory systems. Among the psychological supporting determinants it is possible to note: lack of idea about the future; emotional instability, tension and sharp mood swings; tendency to intellectualization; attractiveness of emerging sensations; development of hedonic attitudes, the desire for self-affirmation. The social determinants that support cyber-addiction include: difficulties in building interpersonal communication; fashion; accessibility.

\section{Classification of types and specificity of manifestations of cyber-addiction, taking into account their stages}

With the progressive development of information and communication technologies (ICT) and the diversification of electronic devices, the diversity of subtypes of cyber-addiction is growing. The most relevant today are: addictive Internet surfing (web-surfing), cybersex (cybersexual addiction), fabbing, virtual dating, passion for online gambling (cyber addiction, online addiction), the obsessive need to be online Internet (Internet addiction, Internet addiction), cyber-communicative addiction (cybercommunicative addiction), gadget addictions, audio / video addiction, television addiction, online gambling, passionate online reading (pathological reading online), cyber- oniomania or selfies (Asieieva, 2020).

Consider some of them in more detail. For example, the passion for online gambling (cyber addiction, online addiction) - a pathological tendency to gamble in virtual casinos.

Online gambling is a hyper-fascination with individual and / or online online games.

Pathological dependence on virtual dating involves hyper-fascination with social networks, dating sites in order to establish new contacts in cyberspace and try on new "self-images" and create new own pages. 


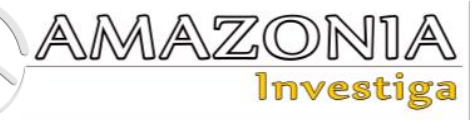

Cybersex (cybersexual addiction) is an irresistible urge to discuss sexual topics in erotic chats, visit pornographic sites and engage in cybersex.

Passionate online reading or pathological online reading is a hyper-fascination with reading both online and downloaded books to a gadget or other electronic device. Modern online books provide the opportunity for the reader to become a co-author, changing the plot of the book through the answers or actions of the characters, provide rewards for opening new chapters, set a time frame for bonuses, that is, reading online books becomes an exciting game with a variety of plots. draws the individual into cyberspace.

Audio / video addiction - listening to music on an audio player, or watching video clips on a gadget or other electronic device.

Cyber-oniomania is the desire to make new purchases in online stores without the need to purchase them and take into account their own financial capabilities, obsessive participation in online auctions.

Cyber-communicative addiction (cybercommunicative addiction) is a special type of Internet addiction, characterized by dependence on communication in the most common communication environment of the Internet social networks. This is a relatively new area of psychological research, however, given the pace of development of social networks, it requires detailed study.

Gadget addiction is a passionate desire to own a specific mobile device or electronic device (laptop, smartphone, iPhone, iPad, etc.) that has access to the Internet and an uncontrolled desire to constantly use this gadget.

Addictive Internet-surfing (web-surfing, websurfing) (from the English "surfing" - surfing) - a pathological passion for constant, superficial wandering on websites. In general, web-surfing is one of the types of Internet use, which is a repeated transition of links from one web page of Internet sites to another. Web surfing does not require any special knowledge or any professional skills. It's easy enough to go to sites, click on links, perform tasks, attract new users, participate in affiliate programs and more.

A relatively new type of cyber-adiation is fabbing (from the English phubbing, from phone - phone + snubbing - contempt) - a bad habit of often being distracted by a mobile phone while talking to someone.

It is also important to note this kind of addiction as "selfie", selfie (English selfie) - a kind of selfportrait, which is to "engrave" yourself on camera. Most often from the distance of the outstretched hand, so the image in the photo has a characteristic angle - at an angle, slightly above or below the head. The habit of taking pictures of yourself, then "post" pictures on "Facebook", "Instagram" or other social networks. Excessive passion for self-photography and posting photos on social networks - is interpreted as selfieism (Selfieism). That is, there is a new trend, a new generation that understands the world through the prism of self-admiration on social networks. Selfitis has become such a global phenomenon that it needs to be considered as a mental disorder in the International Classification of Diseases ICD-11. In the case of such an official classification of "computer addiction", the diagnosis can be made dependent on "selfies", online games, SMS and social networks (Rumpf, Achab, \& Billieux, 2018).

After analyzing the existing research on this issue, according to the authors, it is possible to provide the following definitions of the basic concepts of some types of cyber-adiation.

Cyber-adiation should be understood as a type of non-chemical dependence, which is expressed in a mental disorder caused by an obsessive desire to be constantly in virtual reality, live and be realized in cyberspace through the use of gadgets or electronic devices, despite the destruction of material and social reality. and for the process of life in general (Asieieva, 2020).

Computer addiction (PC) (computer addiction or computer addiction - synonymous concepts) should be understood as a type of non-chemical dependence, which is expressed in the obsessive desire to constantly use a PC, despite the negative impact on physical and mental health ', the destruction of real social relations, and when it is impossible to use it, there are changes in the emotional and volitional sphere of the individual (Asieieva, 2020).

Internet addiction (Internet addiction) is a type of non-chemical addiction, which is interpreted as a mental and behavioral disorder, which is expressed in an obsessive or compulsive desire to be constantly online, causing disruption of normal life, and the inability to stay online leads to changes in emotional state and causes negative 
changes in the cognitive, behavioral and affective spheres of personality (Asieieva, 2020).

Gadget addiction is a type of non-chemical dependence, which is expressed in tracking new versions of mobile or gadget devices on the market, in the hyperbolized need to own a certain model (laptop, smartphone, iPhone, iPad or other electronic device) and uncontrolled desire to use this gadget (Asieieva, 2020).

Cyber-communicative addiction (cybercommunicative addiction) is a type of nonchemical addiction, which is expressed in the obsessive desire to build and maintain interpersonal communication in cyberspace through messengers, social networks, forums, chats, group games, etc., while neglecting the real interconnections. which leads to the destruction of the normal process of life of the individual.

Selfitis is a type of non-chemical dependence, which is expressed in the obsessive desire to constantly self-photograph and post photos on their own pages in cyberspace, and the inability to self-photograph, process photos, post them online, lack of "likes" or positive reviews or negative feedback becomes the cause of negative changes in the emotional-volitional, cognitive and behavioral spheres of personality.

After analyzing the available scientific knowledge on the definitions and classification of addictions, it is possible to propose the following distribution of addictions (Fig. 1). Most scientists distinguish three types of addictions: chemical; intermediate and nonchemical addictions. Chemical and intermediate addictions are not the subject of our study, so let's just list them. Chemical addictions include addictions to alcohol, tobacco, caffeine, opiates, cannabinoids, hallucinogens, various solvents, tranquilizers, barbiturates, and the like.

Intermediate addictions mostly include (F50; F64 F65): anorexia nervosa; atypical anorexia nervosa; bulimia nervosa; atypical bulimia nervosa; overeating associated with other psychological disorders; disorders of sexual identification and disorders of sexual preference, etc.

Among non-chemical addictions it is possible to distinguish: socially acceptable addictions; pathological non-chemical addictions; cyberaddiction. Socially acceptable addictions include: workaholism; religious addiction; addiction to a healthy lifestyle; addiction to relationships; pathological reading; collecting, etc. Pathological non-chemical addictions include: gambling; shopaholism; ziping; television dependence, as well as noise dependence, etc.

Depending on the way of deviating from reality, it is possible to separate three dyads of cyberaddictions: 1st dyad - Introverted includes dependence on PC and Internet addiction; 2nd dyad - Mixed, which includes such types of cyber-addiction as Game Addiction and Gadget Addiction; 3rd dyad - Extraverted includes: Cyber-communicative addiction and Selfitis.

From the addiction agent (from the focus of satisfying a pathological need), it is possible to separate Internet addictions: addictive Internet surfing; cyber- oniomania; pathological online reading. Cybernetic addiction and online gambling can be distinguished as subtypes of game-addiction. As subtypes of cybercommunicative addiction it is possible to separate cybersex, fabing, virtual acquaintances.

Separation in the process of formation of cyberaddictions of certain stages is an important step, as it involves the typology of addicts, which is a necessary condition for effective prevention of addictive behavior.

To date, scientists have identified 4 stages of formation of cyber-addiction: 1) the stage of easy enthusiasm, which only starts the mechanisms of dependence; 2) the stage of enthusiasm, which is characterized by the emergence of a new need constantly playing computer games, browsing the Internet, chatting, the world of cyberspace becomes more attractive, the individual neglects communication with relatives, family affairs and recreation, addiction develops; 3 ) the stage of dependence, at which there are major changes in self-esteem and self-awareness of the addict, which leads to serious changes in the value sphere of the individual; 4) the stage of attachment, which is the longest and is characterized by a shift in psychological content. The rate of attenuation of the addiction depends on which of the previous stages the addict stopped during its formation. If it goes through all stages of development of cyber-addiction, then it, depending on the rate of extinction, can last a lifetime (Rumpf, Achab, \& Billieux, 2018; Borisova, Solta, 2019; Voiskunsky, Smyslova, 2020; Morahan-Martin, 2008). 


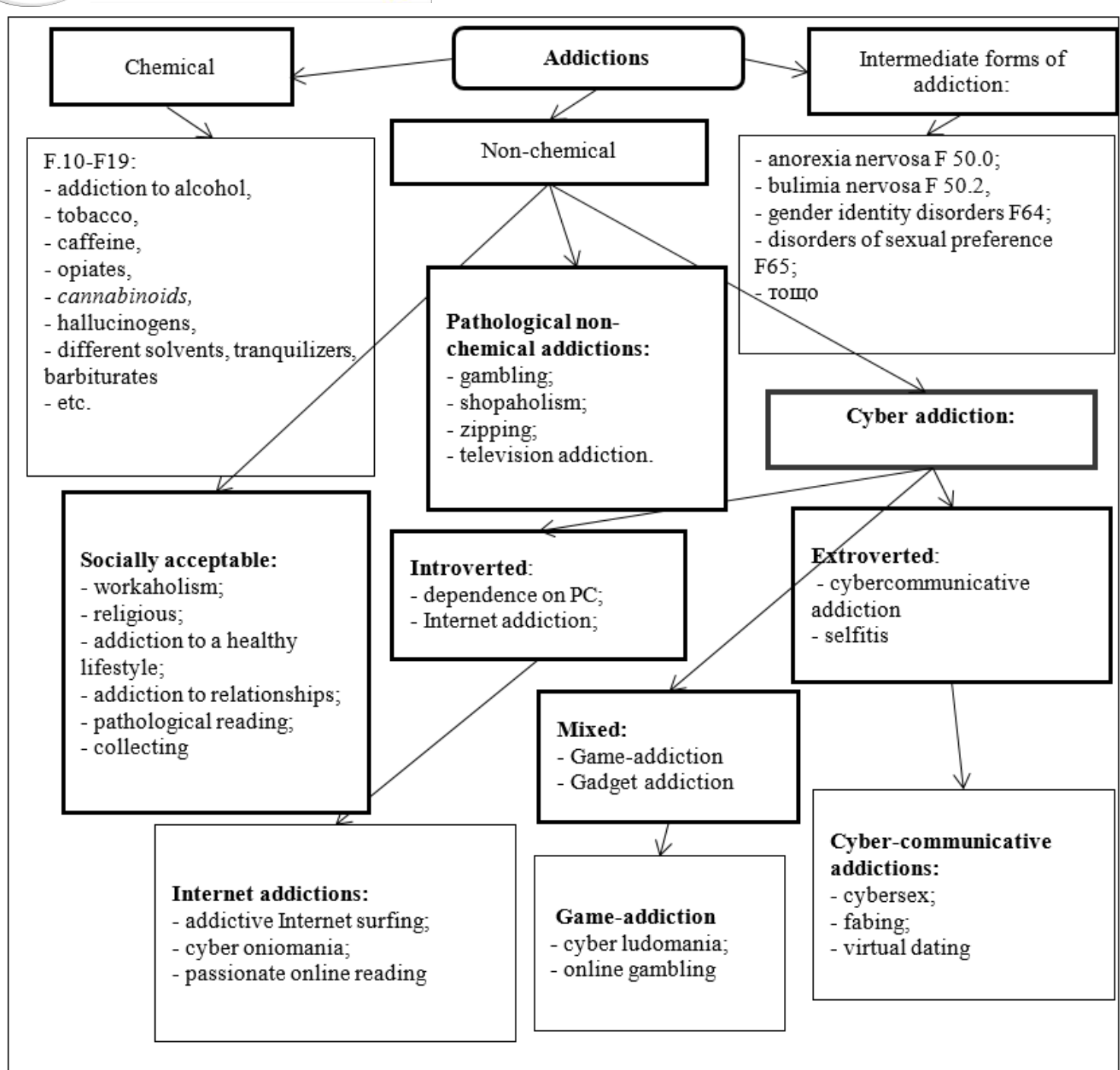

Pic. 1. Addiction classification model. (Author: Yu. Asieieva)

Also, in psychology, a special type of mental states has been described, which exist only in the actual. This type of psychological state has been called "virtual states" and is associated with the concept of "virtual reality", which has a number of specific properties: generation (produced by external to it activity of another reality); relevance (there is relevance, only "here and now", only as long as the activity generates reality); autonomy (has its time, space and laws of existence, for a person who is in virtual reality there is no past and future); interactivity (can interact with all other realities, including those generated as ontologically independent of them) (Nosov, 2000).

Signs that the addiction has formed and is progressing are hiding the true time spent in cyberspace and hiding the nature of the lessons behind it. The amount of time spent in cyberspace increases to several hours. Outside of cyberspace, there is irritation or despair, while using a computer, the Internet, gadgets and other electronic devices, you feel well and euphoric. Being in cyberspace is detrimental to all the vital functions of the body: neglect of sleep, nutrition, ignoring household chores, and so on.

After analyzing the existing approaches to the stages of cyber-addiction, we propose to separate the following:

1) Addictive-pragmatic, the absence of cyberaddiction, at this stage the person has experience and formed an idea of work and use: PC, Internet, some games, gadgets, and have little experience in cybercommunications and selfies. People do not turn to the network every day, control the time they spend in cyberspace when interacting with various gadgets.

2) Comfortable or no pathological signs of cyber-addiction - the use of gadgets and various types of devices, Internet and PC is 
normal, at the level of socially acceptable use of interactive technologies that meet modern needs of society or professional functions.

3) Enthusiasm (or 1st degree of dependence), which does not affect the normal process of life and social interaction of the individual, but there are manifestations of passionate use of cyberspace, gadgets and other electronic devices. At this stage, there are no signs of the formation of a certain type of cyber-addiction. That is, social relationships do not yet suffer, the individual sometimes breaks his promises, sometimes refuses to perform his duties, sometimes the normal biological rhythm is disturbed. The normal process of personality is not yet disturbed.

4) Passion (or 2nd degree of dependence) formed dependence with the emergence of problems that disrupt the normal social life of the individual, suffer and disrupt interpersonal and professional relationships. The individual chooses cyberspace over real life. At this stage, the individual needs outside help, involvement in psychocorrective measures aimed at preventing further formation of pathological dependence.

5) Disadaptation (or 3rd degree) - pathological dependence, which has manifestations of severe social maladaptation of the individual, changes in psycho-emotional characteristics are already detected and physiological disorders are observed (tunnel syndrome, decreased vision, headache, scoliosis, etc.). Personality requires the intervention of specialists, involvement in general psycho-corrective measures aimed at reducing dependence on the identified type of cyber-addiction. This stage already indicates psychophysiological changes that require treatment and active psychocorrectional measures.

Thus, it is possible to note that the problem of cyber-addiction, having a complex multifactorial nature, is similar in its development to other types of dependencies. To date, there are various definitions, criteria, stages and factors of dependence.

\section{Research results dominant cyber-addiction among young people according, the degree of their manifestation.}

In our study, we decided to investigate how common cyber-addictions are among young people and what are the possible combinations of their combinations. To do this, a survey of Internet users was conducted by posting a virtual questionnaire «Test-questionnaire for the detection of cyber-adiation» (TQC) on various sites and forums, including self-developed electronic resources (www.aseevayulia.com). A total of 6,000 respondents (aged 14-21) were interviewed, including 2,940 men $(49 \%)$ and 3,060 women $(51 \%)$ aged 14 to 21 years.

Table 1

Manifestation in the percentage of different stages of cyber-addiction among young people.

\begin{tabular}{|c|c|c|c|c|c|c|c|c|c|c|c|}
\hline \multirow[t]{2}{*}{ Subscales TQC } & \multirow[b]{2}{*}{ 凶. } & \multicolumn{2}{|c|}{$\begin{array}{l}\text { Addictive- } \\
\text { pragmatic }\end{array}$} & \multicolumn{2}{|c|}{ Comfortable } & \multicolumn{2}{|c|}{ Enthusiasm } & \multicolumn{2}{|c|}{ Passion } & \multicolumn{2}{|c|}{ Disadaptation } \\
\hline & & $\mathrm{n}$ & $\%$ & $\mathrm{n}$ & $\%$ & $\mathrm{n}$ & $\%$ & $\mathrm{n}$ & $\%$ & $\mathrm{n}$ & $\%$ \\
\hline \multirow{2}{*}{ Dependence on PC } & B & 38 & 0,63 & 52 & 0,87 & 98 & 1,63 & 114 & 1,90 & 99 & 1,65 \\
\hline & G & 40 & 0,67 & 57 & 0,95 & 95 & 1,58 & 143 & 2,38 & 56 & 0,93 \\
\hline \multirow{2}{*}{ Internet addiction } & $\mathrm{B}$ & 46 & 0,77 & 48 & 0,80 & 126 & 2,10 & 114 & 1,90 & 112 & 1,87 \\
\hline & G & 47 & 0,78 & 45 & 0,75 & 137 & 2,28 & 149 & 2,48 & 79 & 1,32 \\
\hline \multirow{2}{*}{ Game addiction } & $\mathrm{B}$ & 39 & 0,65 & 56 & 0,93 & 187 & 3,12 & 167 & 2,78 & 125 & 2,08 \\
\hline & G & 48 & 0,80 & 59 & 0,98 & 132 & 2,20 & 143 & 2,38 & 68 & 1,13 \\
\hline \multirow{2}{*}{ Gadget addiction } & $\mathrm{B}$ & 41 & 0,68 & 68 & 1,13 & 162 & 2,70 & 146 & 2,43 & 107 & 1,78 \\
\hline & $\mathrm{G}$ & 43 & 0,72 & 78 & 1,30 & 143 & 2,38 & 125 & 2,08 & 84 & 1,40 \\
\hline \multirow{2}{*}{$\begin{array}{l}\text { Cybercommunicativ } \\
\text { e addiction }\end{array}$} & $\mathrm{B}$ & 29 & 0,48 & 84 & 1,40 & 136 & 2,27 & 157 & 2,62 & 98 & 1,63 \\
\hline & $\mathrm{G}$ & 38 & 0,63 & 87 & 1,45 & 148 & 2,47 & 186 & 3,10 & 126 & 2,10 \\
\hline \multirow{2}{*}{ Selfitis } & $\mathrm{B}$ & 37 & 0,62 & 112 & 1,87 & 201 & 3,35 & 98 & 1,63 & 43 & 0,72 \\
\hline & $\mathrm{G}$ & 42 & 0,70 & 124 & 2,07 & 288 & 4,80 & 134 & 2,23 & 116 & 1,93 \\
\hline \multirow{2}{*}{ Total for the article } & $\mathrm{B}$ & 230 & 3,83 & 420 & 7,00 & 910 & 15,17 & 796 & 13,27 & 584 & 9,73 \\
\hline & G & 258 & 4,30 & 450 & 7,5 & 943 & 15,72 & 880 & 14,67 & 529 & 8,82 \\
\hline Total & & 488 & 8,13 & 870 & 14,5 & 1853 & 30,88 & 1676 & 27,93 & 1113 & 18,55 \\
\hline
\end{tabular}




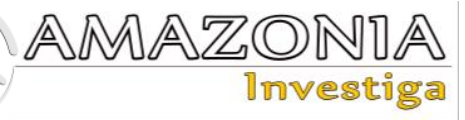

According to the obtained results, it is possible to indicate that 4642 persons show dependence, $77.37 \%$ of respondents, including 2290 boys (38.17\% of respondents) and 2352 girls (39.20\% of respondents). 488 people $(8.13 \%$ of respondents), including 230 boys, which is $3.83 \%$ of respondents and 258 girls, which is $4.30 \%$ of respondents, were found to have no addictions. Without pathological signs of addiction, 870 people were found $(14.50 \%$ of respondents) who control the process of using PCs and the Internet, demonstrate the normal, socially acceptable use of interactive technologies that meet modern needs of society including 420 young people, $00 \%$ of respondents and 450 girls, which is $7.50 \%$ of respondents. Thus, among the younger generation in the age group from 14 to 21 years do not have manifestations of cyber-addiction, are able to control the time spent online or using PCs, gadgets or other electronic devices found only $22.63 \%$ of respondents, including $10.83 \%$ boys, and $11.80 \%$ girls.

Dependence (described indicators of total dependence on the 1st, 2nd and 3rd degree hereinafter the total indicator) from PC show $10.08 \%$ of respondents, of whom boys $-5.18 \%$ of respondents, and girls $4.90 \%$ of respondents. The total rate of Internet addiction was found in $11.95 \%$ of respondents, including boys $-5.87 \%$ of respondents, girls $6.08 \%$ of respondents. The total rate of game addiction was found in $13.70 \%$ of respondents, including boys - $7.98 \%$ of respondents, girls $5.72 \%$ of respondents. The total rate of gadget addiction was found in $12.78 \%$ of respondents, including boys $-6.92 \%$ of respondents, girls $5.87 \%$ of respondents. The total rate of cyber-communicative addiction was found in $14.18 \%$ of respondents, including boys - $6.52 \%$ of respondents, girls $7.67 \%$ of respondents. The total rate of selfitis was found in $14.67 \%$ of respondents, of whom boys $-5.70 \%$ of respondents, girls $8.97 \%$ of respondents.

Thus, it is possible to note that boys in the age group from 14 to 21 years are more prone to addiction to PC, game addiction and gadget addiction, and girls - to cybercommunication addiction and selfitis. This distribution of cyberaddiction among young people can be explained by leading gender interests. Young people in the age group of 14 to 21 are more focused on realizing themselves in cyberspace as experts in certain information technologies, watching software updates of computers, gadgets and other electronic devices. They see the gaining of authority among peers in game success, gaining updates from their cyber-heroes, through which they present themselves and their status in cyberspace. Girls are more interested in establishing interpersonal communication, forming their own image of «I», demonstrating themselves and popularity among peers, forming groups of cyber-supporters, and so on.

\section{Conclusions}

The study allowed us to come to the following conclusions, which were determined by the purpose and objectives.

1. Considering the diverse views of modern scientists, it is possible to note that sociologists consider the fascination with cyberspace as a kind of deviation. Recently, the views of physicians and psychologists are increasingly reduced to the position that cyber-addiction is a pathological urge or disease that belongs to the category of nonchemical dependencies and has its own nosology, etiology, pathogenesis and needs prevention, treatment and psychocorrection.

In a broad sense, cyber-addiction can be defined as a type of non-chemical addiction, expressed in a mental disorder caused by an obsessive desire to be constantly in virtual reality, live and be realized in cyberspace through the use of gadgets or electronic devices, despite the social destruction of material consequences for health and for the process of life in general.

2. In our opinion, among non-chemical addictions it is already possible to distinguish: socially acceptable addictions; pathological non-chemical addictions; cyber-addiction. Socially acceptable addictions include: workaholism; religious; addiction to a healthy lifestyle; addiction to relationships; pathological reading; collecting, etc. Pathological non-chemical addictions include: gambling; shopaholism; ziping; television dependence, as well as noise dependence, etc.

Depending on the way of deviating from reality, it is possible to separate three dyads of cyberaddictions: 1st dyad - Introverted includes dependence on PC and Internet addiction; 2nd dyad - Mixed, which includes such types of cyber-addiction as game addiction and gadget addiction; 3rd dyad - Extraverted includes: cyber-communicative addiction and selfitis.

Depending on the addiction agent (on the direction of satisfying the pathological need), it is possible to distinguish among Internet 
addiction: addictive Internet surfing; cyberoniomania; pathological online reading. Cybernetic addiction and online gambling are separated as subtypes of game-addiction. The subtypes of cyber-communicative addiction include cybersex, fab, virtual dating, and so on.

3. According to the set tasks, an experimental study was conducted to identify the prevalence of cyber-addiction among young people and found that the most typical for young men are: computer addiction, Internet addiction, game addiction and gadget addiction, girls are more typical: cybercommunicative addiction and selfies. When considering age, it is possible to note that the highest rates of 3rd degree of addiction are among persons from 19 to 21 years, more even distribution of 2 nd and 3 rd degrees of addiction among persons in the age group from 14 to 15 years. Due to the analysis of the obtained results, it was established that an addict can have not one dependence, but several, although each of them may have a different degree of manifestation.

Further studies of the specifics and severity of types of cyber-addictions among young people will give us the opportunity not only to describe the psychological characteristics, but also to approach the development of adequate psychological technologies for their prevention, prevention and psychocorrection.

\section{Bibliographic references}

Asieieva, Yu.O. (2020). Computer addiction, Internet addiction and cyber-addiction (historical overview of the definition) Psychological Journal, 6(6), 57-65, DOI: https://doi.org/10.31108/1.2020.6.6 (in Ukraine)

Aymedov, K.V., Asieieva, Yu.A., Tolmachev, A.A., \& Tabachnik, S.I., (2020). Psychological characteristics of persons prone to cybercommunicative addiction on the example of the INSTAGRAM social network. Psychiatry, psychotherapy and clinical psychology, 11(4), p. 731-738. DOI: $10.34883 /$ PI.2020.11.4.006 (in Russian)

Babaeva, Yu.D., Voiskunsky, A.E., \& Smyslova, O.V. (2005). Internet: impact on personality". Psychology of Addiction: A Reader. Minsk: Harvest, p. 175-222, URL: https://istina.msu.ru/publications/article/274 1486/ (in Russian)

Bartkiv, O., \& Makhnovets, V. (2018). Study of students' propensity to Internet addiction.
Youth and the market, no. 2 (121), p. 141146, (in Ukraine)

Belinskaya, E.P. (2013). Informational socialization of adolescents: experience of using social networks and psychological well-being. Psychological research, 6(30), p. 5. URL: http://psystudy.ru/index.php/num/2013v6n3 0/858-belinskaya30.html (in Russian)

Blachnio, A., Przepiorka, A., Benvenuti, M., Mazzoni, E., Gwendolyn, S. (2019). Relations Between Facebook Intrusion, Internet-addiction, Life Satisfaction, and Self-Esteem: a Study in Italy and the USA". International Journal of Mental Health and Addiction, vol. 4. p. 18-38, URL: https://www.springermedizin.de/relationsbetween-facebook-intrusion-internetaddiction-life-sat/16353444 (in English).

Bolbot, T. Yu. (2005). Risk factors for the development of computer addiction in young people with computer addiction (clinic, correction and prevention) (author. dis. ... Cand. honey. Science) Ukrainian Research Institute of Social and Forensic Psychiatry and Addiction of the Ministry of Health of Ukraine. K., 36 p. URL: http://www.irbisnbuv.gov.ua/cgibin/irbis_nbuv/cgiirbis_64.exe?C21COM=2 $\& I 21 \mathrm{DBN}=\mathrm{ARD} \& \mathrm{P} 21 \mathrm{DBN}=\mathrm{ARD} \& Z 21 \mathrm{ID}=$ \&Image_file_name=DOC/2005/05btykkp.zi p\&IMAGE_FILE_DOWNLOAD $=1$ (in Ukrainian)

Boram, J. J., \& Yoon, L. B. et. al. (2020). Associations of personality and clinical characteristics with excessive Internet and smartphone use in adolescents: a structural equation modeling approach. J. Addictive Behaviors, vol. 11. p. 25-33, (in English).

Borisova, T.S., \& Soltan, M.M. (2019). On the possibilities of using the method of medical prevention of computer addiction. Military medicine, no. 3, p. 16-21, (in Russian)

Chebykin, O.Ya. (2016). Psycho-emotional dependence on mobile communication in students with various manifestations of emotional maturity." Science and education, no. 11, p. 30-3. (in Ukrainian)

Egorov, A.Yu. (2007). Non-chemical addictions. St. Petersburg: Rech., p.190 URL: http://lib.mgppu.ru/opacunicode/app/webroo t/index.php?url=/notices/index/IdNotice: 237 217/Source:default (in Russian)

Goldberg. (1996). Internet-addiction disorder". Cyber Psychol. Behavior, 3(4), p. 403-412, URL: https://www.psycom.net/iadcriteria.html_(in English) 


\section{AMAZOND周
Dnvestiga}

Goncharov, V.N. (2011). Research of information processes in the context of determining the value of information. Sociosphere, No. 3 p. 9-10. URL: https://psyjournals.ru/sociosphera/2011/n3/4 6797.shtml (in Ukrainian)

Griffiths, M.D., Kuss, D.J., \& Billieux, J. (2016). The evolution of Internet addiction: A global perspective". Addictive Behaviors, vol. 53, 193-195, (in English)

Grybyuk, O.O. (2014). Demyanenko V.M. System of psychological and pedagogical requirements for the means of information and communication technologies for educational purposes: monograph. K.: Attica, 172 p. (in Ukraine)

Hawi, N. (2018). Identifying commonalities and differences in personality characteristics of Internet and social media addiction profiles: traits, self-esteem, and self-construal. Behavior \& Information Technology. p. 110 119. (in English)

Hiltz, S.R., \& Turoff, M. (1978). The Network Nation: Human Communication via Computer". Reading, Mass., et al.: AddisonWesley, p. 179-189, https://www.academia.edu/604994/The_Net work_Nation_Human_Communication_via_ Computer-Revised_Edition. [Revised Edition. Cambridge, MA: MIT Press, 1993.] https://www.amazon.com/Network-NationRevised-CommunicationComputer/dp/0262581205 (in English)

Markova, M.V. (2013). Addictive status of student youth of Kyiv: psychosocial, clinical and structural analysis. Medical psychology, 8(3), p. 34-41. 2013 URL: http://www.mps.kh.ua/archive/2013/3 (in Ukraine)

Marlatt, G.A., Baer, J.S., Donovan, D.M., \& Kivlahan, D.R. (1988). Addictive behaviors: Etiology and treatment. Annual Review of Psichology, vol. 39, p. 223-252, (in English)

Melnik, E. V. (1998). On the nature of addiction diseases: (alcoholism, drug addiction, "computer science", etc.). Odessa, p. 134159, (in Russian)

Morahan-Martin, J. (2008). Internet abuse: Emerging trends and lingering questions. Psychological aspects of Cyberspace: Theory, research and applications, p. 32-69, URL:

https://digitalcommons.bryant.edu/app_book s/3/ (in English)

Nosov, N.A. (2000). Virtual psychology. M: Agraf, p. 432, (in Russian)

Oravec, J. A. (2012). Online counseling and the Internet: Perspectives for mental health care supervision and education. Journal of Mental Health, 9(2), pp. 121-135.

Pronin, M.A. (2016). Challenges to the worldview of developers of virtual reality technologies (tvr): philosophical, ethical, legal and other consequences. Philosophy of Education, No. 69, p. 46-69. (in Russian)

Rumpf, H.J., \& Achab, S.J. (2018). Billieux "Including gaming disorder in the ICd-11: The need to do so from a clinical and public health perspective". J. Behav Addict, 7(3), p. 556-561, DOI:10.1556/2006.7.2018.59 (in English)

Rybaltovich, D.G (2012). Analysis of questionnaires of Internet users with experience in online play. Journal of Psychotherapy, No.41. S. 67-80. URL: http://easydraw.ru/psy/analiz_anketirovaniya _internet-

polzovatelei_imejushih_opyt_online_igry.ht ml (in Russian)

Rzhevsky, G.M. et al. (2018). Analysis of personal characteristics and causes of Internet addiction in students of higher educational institutions." World Science, vol. 5, no. 1 (29), p. 50-60, URL: https://www.elibrary.ru/item.asp?id=323149 74 (in Ukraine)

Short, J., Williams, E., \& Christie, B. (1976). The social psychology of telecommunications. New York: Wiley, p. 432-474, (in English)

Shotton, M. (1991). The costs and benefits of "computer addiction." Behaviour and Information Technology, 10(3), 219 - 230.

Sidak, L.M. (2015). Addiction as a form of destruction of the spiritual being of the individual. Bulletin of the National University "Law Academy of Ukraine. Yaroslav the Wise". Series: Philosophy, philosophy of law, political science, sociology, no. 4, p. 46-55, (in Ukraine)

Stefanie, O., Streb, K.R., \& Irina, F. (2019). Selfaggression, reactive aggression, and spontaneous aggression: Mediating effects of self-esteem and psychopathology". Aggressive Behavior, vol. 45, p. 31-34, (in English)

Tan, Y. (2016). Exploring associations between problematic internet use, depressive symptoms and sleep disturbance among southern Chinese adolescents. International journal of environmental research and public health, 13(3), pp. 313. (in English)

Tazetdinova, Yu. M. (2018). Theoretical preconditions of research of features of aggressive behavior at teenagers - boys with different level of game computer dependence. St. Petersburg Educational Bulletin, No. 9. pp. 43-48. (in Russian) 
Utz, S. (2015). The function of self-disclosure on social network sites: Not only intimate, but also positive and entertaining self-disclosures increase the feeling of connection. Computers in Human Behavior, no. 45, p. 1-10, DOI:10.1016/j.chb.2014.11.076 (in English)

Voiskunsky, Ye., \& Smyslova, O.V. "Cyber disease in virtual reality systems: key factors and sensory integration". Psychological journal, 41(1), p. 56-64, 2020 URL: https://www.elibrary.ru/item.asp?id=425414 50 (in Russian)

Voloshin, P.V, \& Maruta, N.O. (2017). Main directions of scientific developments in neurology, psychiatry and narcology in Ukraine. Ukrainian Bulletin of Psychoneurology, 25(1), p. 10-18. URL: https://uvnpn.com.ua/upload/iblock/834/834 8a722ce7101d7ac9396a62ddd3cc2.pdf (in Ukraine)

Yaxuan, Ren J., \& Lin Xian, X. (2018). Low selfesteem, entrapment, and reason for living: A moderated mediation model of suicidal ideation". International Journal of Psychology, vol. 6, p. 18-22, (in English)

Young, K.S. (1996). Psychology of computer use: addictive use of the internet: a case that breaks the stereotype. Psychological reports, vol. 79, p. 899-902, (in English)

Zhaojun, M., Pontesbc, Q.N., \& Guangcan, D. (2020). Internet gaming disorder and psychosocial well-being: A longitudinal study of older-aged adolescents and emerging adults. J. Addictive Behaviors, vol. 110, p. 511 ,

URL: https://www.sciencedirect.com/science/articl e/abs/pii/S0306460320306602 (in English)

Zhichkina, A.E. (2010). Self-presentation in virtual communication and identity features of adolescent Internet users. Education and information culture. Sociological aspects. Works on the sociology of education, T. 5 vol. 7. Moscow: Center for Sociology of Education, Russian Academy of Education, p. 431-460. URL: https://istina.msu.ru/publications/article/291 3195/ 